\title{
Emulsified silicone oil droplets blocking an aurolab aqueous drainage implant
}

\author{
Sharmila Rajendrababu, ${ }_{1}^{1}$ Vijayalakshmi A Senthilkumar, ${ }^{1}$ Sagnik Sen (1) ${ }^{2}$
}

${ }^{1}$ Department of Glaucoma, Aravind Eye Hospital, Madurai, Tamil Nadu, India

${ }^{2}$ Department of Vitreo-retina, Aravind Eye Hospital, Madurai, Tamil Nadu, India

\section{Correspondence to Dr Sagnik Sen; riksag@gmail.com}

Accepted 22 July 2020

\section{Check for updates}

(C) BMJ Publishing Group Limited 2020. No commercial re-use. See rights and permissions. Published by BMJ.

To cite: Rajendrababu $S$, Senthilkumar VA, Sen S. BMJ Case Rep 2020;13:e237920. doi:10.1136/bcr-2020-

237920

\section{DESCRIPTION}

Glaucoma drainage devices are commonly used nowadays in cases of secondary glaucoma, especially silicone oil (SO) glaucoma. Even after removal of $\mathrm{SO}$ from the vitreous and anterior chamber, due to remnant droplets in the drainage tube, intractable glaucoma can occur. We hereby report one such case.

A 28-year-old man, known case of Marfan syndrome, presented with secondary glaucoma in left eye (OS) following multiple vitreo-retinal surgery after rhegmatogenous retinal detachment 1 year ago (5000 cs SO in situ). Six months after last vitreoretinal surgery, complete $\mathrm{SO}$ removal was performed owing to high intraocular pressure (IOP), however subsequent follow-up visits showed persistently high IOP, for which he underwent placement of a non-valved glaucoma drainage device (GDD) (Aurolab aqueous drainage implant (AADI), Aurolabs, Madurai, India). AADI was placed in the superotemporal quadrant, as areas of significant scleral thinning were identified in the inferonasal quadrant. The tube length however was longer than usual, measuring $3 \mathrm{~mm}$ in anterior chamber. At 1 month follow-up visit, the tube orientation shifted more horizontally further increasing the tube length and the patient developed high IOP OS which was managed by topical timolol maleate $0.5 \%$ and dorzolamide $2 \%$. After 2 months, the IOP OS was $32 \mathrm{~mm} \mathrm{Hg}$. Slit lamp and gonioscopic evaluation OS revealed bubbles of SO blocking the AADI tube and obscuring the view of the tube ostium (figure 1A,B). High IOP persisted refractory to ocular hypotensive medications, making the eye symptomatic, for which G6 Micropulse diode laser treatment (IRIDEX Cyclo G6 $1500 \mathrm{~mW}$ power and 180 s with $31.3 \%$ duty cycle) was performed.

Incidence of glaucoma after SO injection ranges from $4.8 \%$ and $48 \%$, and emulsification of oil is a major contributor towards the same. ${ }^{1}$ Emulsification involves failure of dispersed oil bubbles to reform into a single large globule and can occur anywhere between 5 and 24 months (mean of 13.2 months) after injection. ${ }^{1}$ This depends on multiple factors, including the purity and viscosity of the oil, fibrinogen, serum, fibrin, blood low density lipoproteins, surfactants on surgical instruments and sterilisation agents. Extravasation of intraocular emulsified oil into the subconjunctival space through sclerotomy and valved GDD has been previously published in literature. ${ }^{2-5}$ However, the same through non-valved devices has not been extensively documented. ${ }^{67}$ We report this to emphasise that elevated IOP can occur even after

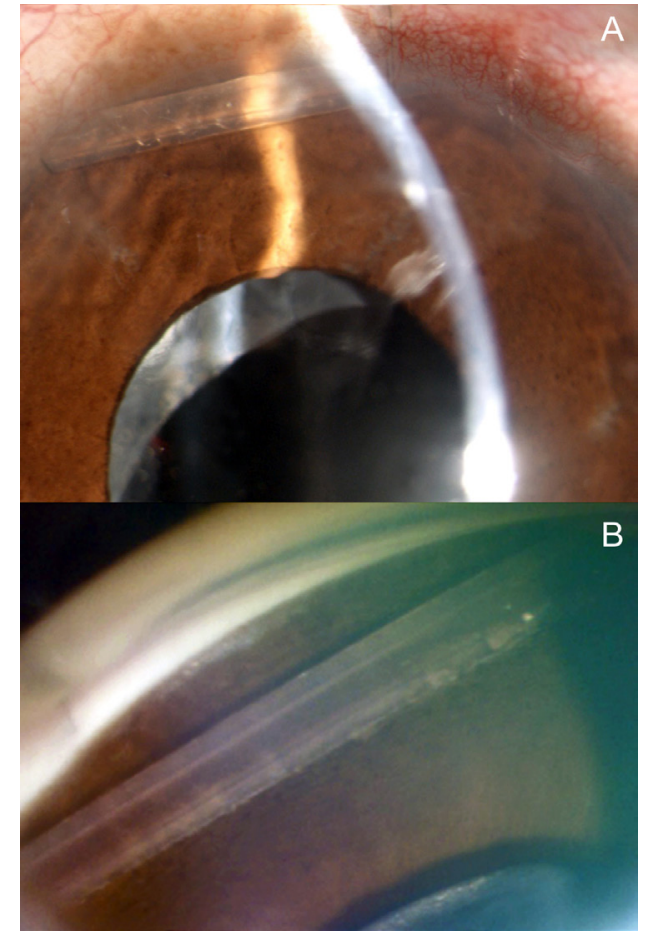

Figure 1 (A) Slit lamp photograph showing the emulsified silicone oil (SO) droplets within the superiorly placed Aurolab aqueous drainage implant (AADI) with long tube in the anterior chamber of left eye. (B) Gonio photograph of the superior angle of left eye showing the long AADI tube with SO droplets in it.

SO removal due to obstruction of a non-valved glaucoma drainage tube by smaller SO droplets. Some modifications which have been proposed to prevent or prolong the development of this extraocular oil migration through tube are usage of a shorter tube

\section{Learning points}

- Understanding the forces and factors that lead to silicone oil (SO) emulsification is crucial in minimising its occurrence.

- It is always recommended to remove SO within 1 year postoperative, unless there is a risk of redetachment, and even if the oil is completely removed before placement of a glaucoma drainage device, residual SO bubbles may still block it.

- Prevention of this complication includes placement of a short tube well anterior to the iris in the inferior portion of the anterior chamber. 
in anterior chamber, pars plana insertion of the drainage tube into the vitreous, placing of tube shunt in the inferonasal quadrant. ${ }^{67}$ High molecular weight and high viscosity SO $(5000 \mathrm{cs})$ is more resistant to dispersion and emulsification and may be preferred, however it is important to remember that even these oils can lead to drainage tube blockage and cause intractable glaucoma, as seen in our patient. ${ }^{6}$

Contributors SR: idea, data collection, writing, proofing. VAS: idea, data collection, writing, proofing. SS: writing, proofing.

Funding The authors have not declared a specific grant for this research from any funding agency in the public, commercial or not-for-profit sectors.

Competing interests None declared.

Patient consent for publication Obtained.

Provenance and peer review Not commissioned; externally peer reviewed.
ORCID iD

Sagnik Sen http://orcid.org/0000-0001-5835-5371

\section{REFERENCES}

1 Ichhpujani P, Jindal A, Jay Katz L. Silicone oil induced glaucoma: a review. Graefes Arch Clin Exp Ophthalmol 2009:247:1585-93.

2 Cunha LP, Primiano Júnior HP, Nakashima A, et al. [Subconjunctival deposit of silicone oil after vitreoretinal surgery]. Arq Bras Oftalmol 2007;70:589-92.

3 Erakgun T, Egrilmez S. Surgical outcomes of transconjunctival sutureless 23-gauge vitrectomy with silicone oil injection. Indian J Ophthalmol 2009;57:105-9.

4 Nazemi PP, Chong LP, Varma R, et al. Migration of intraocular silicone oil into the subconjunctival space and orbit through an Ahmed glaucoma valve. Am J Ophthalmol 2001:132:929-31.

5 Hyung SM, Min JP. Subconjunctival silicone oil drainage through the Molteno implant. Korean J Ophthalmol 1998:12:73-5.

6 Friberg TR, Fanous MM. Migration of intravitreal silicone oil through a Baerveldt tube into the subconjunctival space. Semin Ophthalmol 2004;19:107-8.

7 Chan CK, Tarasewicz DG, Lin SG. Subconjunctival migration of silicone oil through a Baerveldt pars plana glaucoma implant. Br J Ophthalmol 2005;89:240-1.

Copyright 2020 BMJ Publishing Group. All rights reserved. For permission to reuse any of this content visit https://www.bmj.com/company/products-services/rights-and-licensing/permissions/

BMJ Case Report Fellows may re-use this article for personal use and teaching without any further permission.

Become a Fellow of BMJ Case Reports today and you can:

- Submit as many cases as you like

- Enjoy fast sympathetic peer review and rapid publication of accepted articles

- Access all the published articles

- Re-use any of the published material for personal use and teaching without further permission

Customer Service

If you have any further queries about your subscription, please contact our customer services team on +44 (0) 2071111105 or via email at support@bmj.com.

Visit casereports.bmj.com for more articles like this and to become a Fellow 